
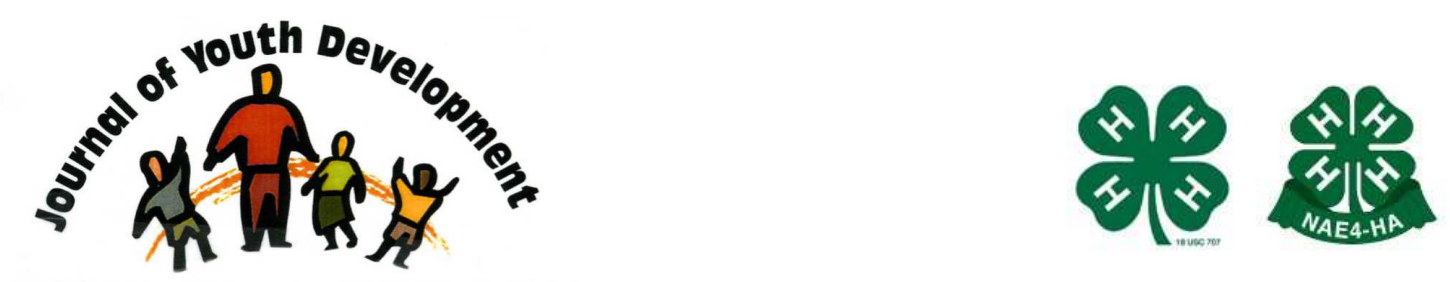

Bridging Research \& Practice

\title{
Consistency of Developmental Outcomes of 4-H Camp Experiences Over Time and Across Sites
}

\author{
Sarah Baughman \\ Agricultural \& Extension Education \\ Virginia Polytechnic Institute \& State University \\ Blacksburg, VA \\ baughman@vt.edu \\ Barry A. Garst \\ American Camp Association \\ Martinsville, IN \\ bgarst@acacamps.org \\ Nicholas E. Fuhrman \\ Agricultural Leadership, Education \& Communications \\ University of Georgia \\ Athens, GA \\ fuhrman@uga.edu
}




\title{
JOURNAL OF YOUTH DEVELOPMENT \\ bridging research and practice

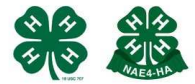

Volume 4, Number 2, Summer 2009

Article 090402FA002

\section{Consistency of Developmental Outcomes of 4-H Camp Experiences Over Time and Across Sites}

\author{
Sarah Baughman \\ Virginia Polytechnic Institute and State University \\ Barry A. Garst \\ American Camp Association \\ Nicholas E. Fuhrman \\ University of Georgia
}

\begin{abstract}
The purpose of the reported trend study was to examine consistency in youth life skill outcomes following exposure to 4-H camp. Parents of campers ages 9 to 13 were randomly sampled in 2001, 2004, and 2007 and asked to report changes in their child's behavior following camp. Statistical analysis indicates an overall consistency in parent reports of youth life skill development over time. Life skills that showed consistent gains over seven years and across six 4-H educational centers included an enhanced ability for youth to take care of their own things and to share work responsibilities. Multivariate statistics revealed that a standardized instrument used with parents over time can produce valid and reliable results concerning the impact of experiential learning on youth.
\end{abstract}

\section{Introduction and Background}

Over the past decade a broad body of literature has emerged in support of the developmental outcomes of camp experiences for children and adolescents (Bialeschki, Henderson \& James, 2007; Garst \& Bruce, 2003; Garton, Miltenberger \& Pruett, 2007; Thurber, Schuler, Scanlin, \& Henderson, 2007). Indeed, previous national research indicates that camp experiences contribute to positive growth in relationship-oriented outcomes such as friendship skills, peer relationships, social comfort, leadership, values, and decision-making (ACA, 2005).

As camp program evaluation has evolved, researchers and camp administrators have explored evaluation approaches for measuring outcomes from the perspectives of different stakeholders (Brandt, \& Arnold, 2006; Ferrari \& McNeely, 2007; Garst \& Johnson, 2005). In fact, evaluation 
of the perspectives of multiple camp stakeholder groups is a standard of practice according to the American Camp Association (ACA, 2007), the national accrediting body of day and resident camps. The standard indicates that camps should have "written evidence of multiple sources of feedback on the accomplishment of the established outcomes related to all aspects of program and operation" in order to improve the quality of the camp experience (p. 179).

The evaluation model for Virginia's 4-H camping program includes:

(a) surveying campers, teen counselors, collegiate staff, adult volunteers and extension agents after completion of a one-week camp experience and

(b) surveying parents/guardians every three years.

Involving parents as stakeholders is an important component of the evaluation model.

Fitzpatrick, Saunders and Worthen (2004) state that a frequent mistake of evaluation plans is to not include input from important audiences and stakeholder groups.

The reported study was grounded in a positive youth development approach that emphasizes the developmental assets of youth. Camp Directors, as youth development professionals can maximize the development of life skills in settings that promote healthy child development. The Targeting Life Skills (TLS) Model (Hendricks, 1996) provided the conceptual framework for the planning, implementation and evaluation of the Virginia 4-H camping program evaluation. The TLS model, which identifies specific, measurable life skills for which the outcomes of youth development programs can be developed and evaluated, has been successfully used in previous research to evaluate camp outcomes (Arnold, Bourdeau \& Nagele, 2005; Garst \& Bruce, 2003; Hines \& Riley, 2005).

The purpose of this study was to explore the developmental outcomes of camp experiences as identified by parents and guardians. The primary research questions were:

1. What changes in youth life skill behaviors will parents/guardians attribute to a five day residential 4-H camping experience?

2. According to parents/guardians, how consistently are campers gaining life skills across multiple camps and years?

3. How do male and female youth differ in terms of life skill development associated with a five day residential 4-H camping experience?

\section{Methods}

Virginia Tech faculty collaborated with camp directors from Virginia's 4-H educational centers to develop a triennial camp evaluation (Appendix). The Virginia 4-H camping program annually involves approximately 15,000 youth who attend one week of residential camp at one of six regional 4-H educational centers. A sample of parents of youth attending a 4-H residential camp were surveyed in $2001(n=363), 2004(n=326)$, and $2007(n=306)$ to determine if life skills learned at camp impacted behavior changes when campers returned home. Response rates were $46 \%$ for $2001,31 \%$ for 2004 and $34 \%$ for 2007 . This approach was important for assessing camp program consistency and quality and for triangulation with collected camper and staff data.

A consistent methodology was used across the three survey years. A systematic random sample of male and female campers, ages 9-13, from each of the six 4-H Educational centers was selected. The parents/guardians of each sampled camper received a mailed questionnaire 
two weeks following their child's camp experience. A follow-up post card was sent four weeks later to increase response rate (Dillman, 2007). The parent survey included questions regarding satisfaction with camp, intentions to continue participation, and a 24-item section that assessed life skill behavior change (comparing life skill behaviors before and after the 4- $\mathrm{H}$ camping experience) across eight domains of the TLS Model: living; being; giving; caring; relating; thinking; managing, and working. The questionnaire items were constructed using a retrospective pre-test approach (Marshall, Higginbotham, Harris \& Lee, 2007; Rockwell \& Kohn, 1989).

\section{Results}

\section{Trend Analysis}

The first research question was, "What changes in youth life skill behaviors will parents/ guardians attribute to a five day residential 4-H camping experience?" To answer this question, parents were asked to rate their child's life skills before and after the residential camp experience. Means for "before camp" and "after camp" ratings were calculated. A comparison of means of life skill behavior impacts across all survey years was constructed to examine changes in parent perceptions. Paired t-test comparisons were made between each of the "before camp" and "after camp" means for each sample. Practical significance of differences was calculated using Cohen's d to determine effect size [Table 1]. Ary, Jacobs, Razavieh and Sorensen (2006) suggest reporting effect size to assess the magnitude of difference between two or more groups and convey practical significance to the research consumer. The majority of items had a medium effect size indicating the difference between the means was at least equal to half a standard deviation.

Table 1

Statistical and Practical Significance of Camper Life Skill Behaviors by Year

\begin{tabular}{|c|c|c|c|c|c|c|c|c|c|}
\hline \multirow[b]{2}{*}{ Life skill item } & \multicolumn{3}{|c|}{$\begin{array}{c}2001 \\
(n=363)\end{array}$} & \multicolumn{3}{|c|}{$\begin{array}{c}2004 \\
(n=326)\end{array}$} & \multicolumn{3}{|c|}{$\begin{array}{c}2007 \\
(n=306)\end{array}$} \\
\hline & $t$ & $d$ & Interp & $t$ & $d$ & Interp. & $t$ & $d$ & Interp. \\
\hline Takes care of his/her own things & $9.55^{*}$ & 0.72 & M & 8.84* & 0.71 & $\bar{M}$ & 7.64* & 0.61 & M \\
\hline Shares work responsibilities & 2.36 & 0.18 & $\mathrm{~S}$ & 7.97* & 0.64 & M & $\begin{array}{c}10.07 \\
*\end{array}$ & 0.81 & $\mathrm{~L}$ \\
\hline Takes initiative and is a self-starter & $8.31 *$ & 0.63 & M & $6.90 *$ & 0.56 & M & $6.84 *$ & 0.55 & M \\
\hline $\begin{array}{l}\text { Takes responsibility for his/her own } \\
\text { actions }\end{array}$ & 7.43* & 0.56 & M & $7.42 *$ & 0.60 & M & $6.47^{*}$ & 0.52 & $M$ \\
\hline Handles success and failures & $7.67 *$ & 0.58 & M & 7.09* & 0.57 & M & $6.20^{*}$ & 0.50 & M \\
\hline Has a good mental attitude & $7.95^{*}$ & 0.60 & M & $5.15^{*}$ & 0.41 & M & $8.34 *$ & 0.67 & M \\
\hline Tries to find answers to questions & $6.76^{*}$ & 0.51 & M & $8.22 *$ & 0.66 & M & 0.14 & 0.01 & $\mathrm{~N}$ \\
\hline Adapts to change & 7.84* & 0.59 & M & 7.06* & 0.57 & M & 7.34* & 0.59 & M \\
\hline Listens to the opinions of others & $6.69 *$ & 0.51 & M & $7.35^{*}$ & 0.59 & M & $7.52 *$ & 0.60 & M \\
\hline Tries to find solutions to problems & 7.33* & 0.55 & M & 7.89* & 0.63 & M & $6.56^{*}$ & 0.53 & M \\
\hline Deals effectively with conflict & $7.30 *$ & 0.55 & M & $7.00 *$ & 0.56 & M & $7.19 *$ & 0.58 & M \\
\hline $\begin{array}{l}\text { Considers choices before making a } \\
\text { decision }\end{array}$ & $7.45^{*}$ & 0.56 & $M$ & 7.84* & 0.63 & $M$ & 7.33* & 0.59 & $M$ \\
\hline
\end{tabular}

Note. *significant at alpha=.001; $\mathrm{d}=$ =Cohen's $\mathrm{d}$ coefficient of effect size; $\mathrm{N}=$ negligible effect size, $\mathrm{S}=$ small effect size, $M=$ medium effect size, $L=$ large effect size 
Table 2 illustrates the life skills with the greatest mean changes over the three data sets. In 2001, the six life skills with greatest positive changes were: "takes care of his/her own things," "shares work responsibilities," "takes initiative and is a self-starter," "takes responsibility for his/her own actions," "handles success and failures," and "has a good mental attitude." In 2004, the six life skills with the greatest positive changes were: "shares work responsibilities," "tries to find answers to questions," "takes responsibility for his/her own actions," "adapts to change," "listens to the opinions of others," and "tries to find solutions to problems." Similarly, in 2007, the six life skills with the greatest positive changes were: "shares work responsibilities," "takes care of his/her own things," "has a good mental attitude," "listens to the opinions of others," "deals effectively with conflict," and "considers choices before making a decision."

Table 2

Changes in Life Skill Behaviors over Time

\begin{tabular}{|c|c|c|c|c|c|c|c|c|c|}
\hline \multirow[b]{2}{*}{ Life skill item } & \multicolumn{3}{|c|}{$\begin{array}{c}2001 \\
(n=363)\end{array}$} & \multicolumn{3}{|c|}{$\begin{array}{c}2004 \\
(n=326)\end{array}$} & \multicolumn{3}{|c|}{$\begin{array}{c}2007 \\
(n=306)\end{array}$} \\
\hline & $\begin{array}{l}\text { Before } \\
\text { camp } \\
\text { mean }\end{array}$ & $\begin{array}{l}\text { After } \\
\text { camp } \\
\text { mean }\end{array}$ & $\begin{array}{c}\text { Change } \\
\text { Score }\end{array}$ & $\begin{array}{l}\text { Before } \\
\text { Camp } \\
\text { mean }\end{array}$ & $\begin{array}{l}\text { After } \\
\text { camp } \\
\text { mean }\end{array}$ & $\begin{array}{c}\text { Change } \\
\text { Score }\end{array}$ & $\begin{array}{l}\text { Before } \\
\text { camp } \\
\text { mean }\end{array}$ & $\begin{array}{l}\text { After } \\
\text { camp } \\
\text { mean }\end{array}$ & $\begin{array}{c}\text { Change } \\
\text { Score }\end{array}$ \\
\hline $\begin{array}{l}\text { Takes care of his/her } \\
\text { own things }\end{array}$ & $\begin{array}{c}3.61 \\
(1.08)\end{array}$ & $\begin{array}{l}3.98 \\
(.95)\end{array}$ & .37 & $\begin{array}{l}3.67 \\
(.98)\end{array}$ & $\begin{array}{l}3.98 \\
(.91)\end{array}$ & .31 & $\begin{array}{l}3.67 \\
(.98)\end{array}$ & $\begin{array}{l}3.98 \\
(.91)\end{array}$ & .31 \\
\hline $\begin{array}{l}\text { Shares work } \\
\text { responsibilities }\end{array}$ & $\begin{array}{c}3.63 \\
(2.06)\end{array}$ & $\begin{array}{l}3.89 \\
(.88)\end{array}$ & .26 & $\begin{array}{l}3.60 \\
(.91)\end{array}$ & $\begin{array}{l}3.91 \\
(.83)\end{array}$ & .31 & $\begin{array}{l}3.60 \\
(.91)\end{array}$ & $\begin{array}{l}3.91 \\
(.83)\end{array}$ & .31 \\
\hline $\begin{array}{l}\text { Takes initiative and is } \\
\text { a self-starter }\end{array}$ & $\begin{array}{c}3.58 \\
(1.01)\end{array}$ & $\begin{array}{l}3.82 \\
(.93)\end{array}$ & .24 & & & & & & \\
\hline $\begin{array}{l}\text { Takes responsibility } \\
\text { for his/her own } \\
\text { actions }\end{array}$ & $\begin{array}{l}3.72 \\
(.96)\end{array}$ & $\begin{array}{l}3.95 \\
(.83)\end{array}$ & .23 & $\begin{array}{l}3.82 \\
(.83)\end{array}$ & $\begin{array}{l}4.09 \\
(.98)\end{array}$ & .27 & $\begin{array}{l}3.82 \\
(.83)\end{array}$ & $\begin{array}{l}4.09 \\
(.98)\end{array}$ & .27 \\
\hline $\begin{array}{l}\text { Handles success and } \\
\text { failures }\end{array}$ & $\begin{array}{l}3.73 \\
(.87)\end{array}$ & $\begin{array}{l}3.96 \\
(.79)\end{array}$ & .23 & & & & & & \\
\hline $\begin{array}{l}\text { Has a good mental } \\
\text { attitude }\end{array}$ & $\begin{array}{l}4.10 \\
(.87)\end{array}$ & $\begin{array}{l}4.33 \\
(.75)\end{array}$ & .23 & & & & & & \\
\hline $\begin{array}{l}\text { Tries to find answers } \\
\text { to questions }\end{array}$ & & & & $\begin{array}{l}3.90 \\
(.95)\end{array}$ & $\begin{array}{l}4.18 \\
(.79)\end{array}$ & .28 & $\begin{array}{l}3.90 \\
(95)\end{array}$ & $\begin{array}{l}4.18 \\
(.79)\end{array}$ & .28 \\
\hline Adapts to change & $\begin{array}{l}3.89 \\
(.89)\end{array}$ & $\begin{array}{l}4.12 \\
(.80)\end{array}$ & .23 & $\begin{array}{l}3.88 \\
(.87)\end{array}$ & $\begin{array}{l}4.15 \\
(.82)\end{array}$ & .27 & $\begin{array}{l}3.88 \\
(.87)\end{array}$ & $\begin{array}{l}4.15 \\
(.77\end{array}$ & .27 \\
\hline $\begin{array}{l}\text { Listens to the } \\
\text { opinions of others }\end{array}$ & & & & $\begin{array}{l}3.83 \\
(.88)\end{array}$ & $\begin{array}{l}4.10 \\
(.77)\end{array}$ & .27 & $\begin{array}{l}3.83 \\
(.88)\end{array}$ & $\begin{array}{l}4.10 \\
(.77)\end{array}$ & .27 \\
\hline $\begin{array}{l}\text { Tries to find solutions } \\
\text { to problems }\end{array}$ & & & & $\begin{array}{l}3.93 \\
(.89)\end{array}$ & $\begin{array}{l}4.19 \\
(.80)\end{array}$ & .26 & $\begin{array}{l}3.93 \\
(.89)\end{array}$ & $\begin{array}{l}4.19 \\
(.80)\end{array}$ & .26 \\
\hline
\end{tabular}

Shading indicates change scores, although still positive, were not among the largest for that year. 
The second research question was how consistently are campers gaining life skills across multiple camps and years? Two-way analysis of variance (ANOVA) was used to test the null hypothesis that no significant difference existed in youth life skill development between the three data collection years $(a=0.05)$. Principal component factor analysis was used to determine broader life skill constructs gained by youth during the 2001 data collection period. Varimax rotation was used to aid in the interpretation of factor loadings.

Four life skill factors emerged from the 2001 data and summated scale scores were computed for each of the four factors. The same items comprising each of these four 2001 factors were then used to develop summated scale scores for the 2004 and 2007 data collection years for the purposes of direct comparison between years (David Miller, Professor of Educational Psychology, personal communication, April 9, 2008). Prior to developing summated scale scores from the 2004 and 2007 data, reliability coefficients (Cronbach's alpha) were calculated for the four 2004 and 2007 predetermined factors to ensure consistency in interpretation.

Results of the ANOVA indicated that no significant difference existed in youth life skill development between the three data collection years $(F=0.001, p=0.989)$. Therefore, the null hypothesis was retained. This provides evidence of consistency in life skill attainment and perhaps program delivery style across the six 4-H educational centers in Virginia.

The third research question was, "How do male and female youth differ with regards to life skill development associated with a one-week residential 4-H camping experience?" (Tables 3 \& 4). Similarities and differences between life skill outcomes for male and female campers were compared. Male campers tended to have a greater degree of change (2004 \& 2007) than female campers (as indicated by gain scores). Similarities were marked by a sharing each year of two of the top seven life skill outcomes by male and female campers, including "shares work responsibilities," and "takes care of his/her own things." These similarities indicate individual camper (rather than gender-related) benefits as perceived by parents/guardians and points to an appropriateness in activities and curricula within the camping structure for both genders.

Correlation analyses revealed no significant associations between prior camp experience, gender and race and each of the four life skill factors at $a=0.05$ level. 
Table 3

Gain Score Rankings of Female Campers

\begin{tabular}{|c|c|c|c|c|c|c|c|c|c|}
\hline \multirow[b]{2}{*}{ Life skill item } & \multicolumn{3}{|c|}{$\begin{array}{c}2001 \\
(n=192)\end{array}$} & \multicolumn{3}{|c|}{$\begin{array}{c}2004 \\
(n=154)\end{array}$} & \multicolumn{3}{|c|}{$\begin{array}{c}2007 \\
(n=154)\end{array}$} \\
\hline & $\begin{array}{l}\text { Before } \\
\text { camp } \\
\text { mean }\end{array}$ & $\begin{array}{l}\text { After } \\
\text { camp } \\
\text { mean }\end{array}$ & $\begin{array}{l}\text { Change } \\
\text { score }\end{array}$ & $\begin{array}{l}\text { Before } \\
\text { camp } \\
\text { mean }\end{array}$ & $\begin{array}{l}\text { After } \\
\text { camp } \\
\text { mean }\end{array}$ & $\begin{array}{l}\text { Change } \\
\text { Score }\end{array}$ & $\begin{array}{l}\text { Before } \\
\text { Camp } \\
\text { mean }\end{array}$ & $\begin{array}{l}\text { After } \\
\text { camp } \\
\text { mean }\end{array}$ & $\begin{array}{l}\text { Change } \\
\text { score }\end{array}$ \\
\hline $\begin{array}{l}\text { Takes care of } \\
\text { his/her own } \\
\text { things }\end{array}$ & $\begin{array}{l}3.77 \\
(1.05)\end{array}$ & $\begin{array}{l}4.11 \\
(.91)\end{array}$ & .34 & $\begin{array}{l}3.74 \\
(1.01)\end{array}$ & $\begin{array}{l}3.97 \\
(.96)\end{array}$ & .24 & $\begin{array}{l}3.74 \\
(.96)\end{array}$ & $\begin{array}{l}3.96 \\
(.86)\end{array}$ & .24 \\
\hline $\begin{array}{l}\text { Takes } \\
\text { responsibility } \\
\text { for his/her } \\
\text { actions }\end{array}$ & $\begin{array}{l}3.77 \\
(.94)\end{array}$ & $\begin{array}{l}4.03 \\
(.82)\end{array}$ & .26 & * & & & & & \\
\hline $\begin{array}{l}\text { Takes initiative } \\
\text { and is a self } \\
\text { starter }\end{array}$ & $\begin{array}{l}3.73 \\
(.95)\end{array}$ & $\begin{array}{l}3.97 \\
(.87)\end{array}$ & .24 & $*$ & & & & & \\
\hline $\begin{array}{l}\text { Shares work } \\
\text { responsibility }\end{array}$ & $\begin{array}{l}3.83 \\
(2.51)\end{array}$ & $\begin{array}{l}4.06 \\
(.81)\end{array}$ & .23 & $\begin{array}{l}3.72 \\
(.96)\end{array}$ & $\begin{array}{l}3.96 \\
(.86)\end{array}$ & .24 & $\begin{array}{l}3.72 \\
(.96)\end{array}$ & $\begin{array}{l}3.96 \\
(.86)\end{array}$ & .23 \\
\hline $\begin{array}{l}\text { Participates in } \\
\text { a discussion }\end{array}$ & $\begin{array}{l}4.12 \\
(.91)\end{array}$ & $\begin{array}{l}4.34 \\
(.79)\end{array}$ & .23 & * & & & & & \\
\hline $\begin{array}{l}\text { Adapts to } \\
\text { change }\end{array}$ & $\begin{array}{l}3.95 \\
(.90)\end{array}$ & $\begin{array}{l}4.17 \\
(.80)\end{array}$ & .23 & $\begin{array}{l}3.96 \\
(.86)\end{array}$ & $\begin{array}{l}4.15 \\
(.85)\end{array}$ & .19 & $\begin{array}{l}3.96 \\
(.86)\end{array}$ & $\begin{array}{l}4.15 \\
(.85)\end{array}$ & .19 \\
\hline $\begin{array}{l}\text { Tries to find } \\
\text { answers to } \\
\text { questions }\end{array}$ & $*$ & & & $\begin{array}{l}3.97 \\
(.86)\end{array}$ & $\begin{array}{l}4.16 \\
(.79)\end{array}$ & .19 & $\begin{array}{l}3.97 \\
(.86)\end{array}$ & $\begin{array}{l}4.16 \\
(.78)\end{array}$ & .19 \\
\hline $\begin{array}{l}\text { Tries to find } \\
\text { solutions to } \\
\text { problems }\end{array}$ & & & & $\begin{array}{l}3.96 \\
(.85)\end{array}$ & $\begin{array}{l}4.15 \\
(.78)\end{array}$ & .19 & $\begin{array}{l}3.96 \\
(.85)\end{array}$ & $\begin{array}{l}4.15 \\
(.78)\end{array}$ & .19 \\
\hline $\begin{array}{l}\text { Listens to the } \\
\text { opinions of } \\
\text { others }\end{array}$ & & & & $\begin{array}{l}3.94 \\
(.86)\end{array}$ & $\begin{array}{l}4.13 \\
(.77)\end{array}$ & .19 & $\begin{array}{l}3.96 \\
(.86)\end{array}$ & $\begin{array}{l}4.13 \\
(.77)\end{array}$ & .19 \\
\hline
\end{tabular}

*Change scores reported only for top six largest changes. Shading indicates change scores, although still positive, were not among the largest. 
Table 4

Change Score Rankings of Male Campers

\begin{tabular}{|c|c|c|c|c|c|c|c|c|c|}
\hline \multirow[b]{2}{*}{$\begin{array}{l}\text { Life skill } \\
\text { Behavior }\end{array}$} & \multicolumn{3}{|c|}{$\begin{array}{c}2001 \\
(n=113)\end{array}$} & \multicolumn{3}{|c|}{$\begin{array}{c}2004 \\
(n=126)\end{array}$} & \multicolumn{3}{|c|}{$\begin{array}{c}2007 \\
(n=126)\end{array}$} \\
\hline & $\begin{array}{l}\text { Before } \\
\text { camp } \\
\text { mean }\end{array}$ & $\begin{array}{l}\text { After } \\
\text { camp } \\
\text { mean }\end{array}$ & $\begin{array}{l}\text { Change } \\
\text { score }\end{array}$ & $\begin{array}{l}\text { Before } \\
\text { camp } \\
\text { mean }\end{array}$ & $\begin{array}{l}\text { After } \\
\text { camp } \\
\text { mean }\end{array}$ & $\begin{array}{l}\text { Change } \\
\text { Score }\end{array}$ & $\begin{array}{l}\text { Before } \\
\text { Camp } \\
\text { mean }\end{array}$ & $\begin{array}{l}\text { After } \\
\text { camp } \\
\text { mean }\end{array}$ & $\begin{array}{l}\text { Change } \\
\text { score }\end{array}$ \\
\hline $\begin{array}{l}\text { Takes care of } \\
\text { his own } \\
\text { things }\end{array}$ & $\begin{array}{l}3.36 \\
(1.09)\end{array}$ & $\begin{array}{l}3.78 \\
(.99)\end{array}$ & .42 & $\begin{array}{l}3.62 \\
(.92)\end{array}$ & $\begin{array}{l}4.02 \\
(.87)\end{array}$ & .40 & $\begin{array}{l}3.62 \\
(.92)\end{array}$ & $\begin{array}{l}4.02 \\
(.87)\end{array}$ & .40 \\
\hline $\begin{array}{l}\text { Shares work } \\
\text { responsibility }\end{array}$ & $\begin{array}{l}3.30 \\
(1.03)\end{array}$ & $\begin{array}{l}3.61 \\
(.93)\end{array}$ & .31 & $\begin{array}{l}3.51 \\
(.84)\end{array}$ & $\begin{array}{l}3.88 \\
(.78)\end{array}$ & .37 & \begin{tabular}{|l|}
3.51 \\
$(.84)$
\end{tabular} & $\begin{array}{l}3.88 \\
(.78)\end{array}$ & .37 \\
\hline $\begin{array}{l}\text { Takes } \\
\text { initiative/is a } \\
\text { self starter }\end{array}$ & $\begin{array}{l}3.36 \\
(1.08)\end{array}$ & $\begin{array}{l}3.60 \\
(.97)\end{array}$ & .24 & & & & & & \\
\hline $\begin{array}{l}\text { Adapts to } \\
\text { change }\end{array}$ & $\begin{array}{l}3.78 \\
(.88)\end{array}$ & $\begin{array}{l}4.02 \\
(.87)\end{array}$ & .24 & $\begin{array}{l}3.82 \\
(.87)\end{array}$ & $\begin{array}{l}4.16 \\
(.76)\end{array}$ & .34 & \begin{tabular}{|l|}
3.82 \\
$(.87)$
\end{tabular} & $\begin{array}{l}4.16 \\
(.76)\end{array}$ & .34 \\
\hline $\begin{array}{l}\text { Has a good } \\
\text { mental } \\
\text { attitude }\end{array}$ & $\begin{array}{l}3.96 \\
(.93)\end{array}$ & $\begin{array}{l}4.20 \\
(.87)\end{array}$ & .24 & & & & & & \\
\hline $\begin{array}{l}\text { Sets goals for } \\
\text { himself }\end{array}$ & $\begin{array}{l}3.34 \\
(.95)\end{array}$ & $\begin{array}{l}3.58 \\
(.90)\end{array}$ & .24 & & & & & & \\
\hline $\begin{array}{l}\text { Tries to find } \\
\text { answers to } \\
\text { questions }\end{array}$ & & & & $\begin{array}{l}3.82 \\
(1.02)\end{array}$ & $\begin{array}{l}4.21 \\
(.81)\end{array}$ & .39 & $\begin{array}{l}3.82 \\
(1.02)\end{array}$ & $\begin{array}{l}4.21 \\
(.81)\end{array}$ & .39 \\
\hline $\begin{array}{l}\text { Tries to find } \\
\text { solutions to } \\
\text { problems }\end{array}$ & & & & & & & & & \\
\hline $\begin{array}{l}\text { Listens to the } \\
\text { opinions of } \\
\text { others }\end{array}$ & & & & & & & & & \\
\hline $\begin{array}{l}\text { Participates in } \\
\text { discussion }\end{array}$ & & & & $\begin{array}{l}4.09 \\
(.88)\end{array}$ & $\begin{array}{l}4.45 \\
(.65)\end{array}$ & .36 & $\begin{array}{l}4.09 \\
(.88)\end{array}$ & $\begin{array}{l}4.45 \\
(.65)\end{array}$ & .36 \\
\hline $\begin{array}{l}\text { Takes } \\
\text { responsibility } \\
\text { for his own } \\
\text { actions }\end{array}$ & & & & $\begin{array}{l}3.67 \\
(.98)\end{array}$ & $\begin{array}{l}4.02 \\
(.84)\end{array}$ & .35 & $\begin{array}{l}3.67 \\
(.98)\end{array}$ & $\begin{array}{l}4.02 \\
(.84)\end{array}$ & .35 \\
\hline
\end{tabular}

Shading indicated change scores, although still positive, were not among the largest for that year.

\section{Conclusions}

Results indicate that the Virginia 4-H camping program consistently increased youth life skills over seven areas from 2001 to 2007. The top two life skills, "shares work responsibilities" and "takes care of his/her own things" have been the steadiest. These results reflect an overall program quality from year to year despite expected organizational changes in staffing, food, facilities and activities. The minor variations in rank from year to year may be the result of normal developmental differences in youth that one would expect to find in such a large population. 
The similarities in life skill gains between boys and girls are promising. This result suggests that the Virginia 4-H camping program provides a positive youth development setting for both boys and girls. The gender differences found in life skill gains may be understood as the developmental differences of male and female youth between the ages of 9-13. These results may also suggest that there are gender-specific benefits of camp participation, based upon social influences of participating with other male and female campers and adults, genderspecific behaviors that campers learn (or un-learn) in camp classes and camp activities. Additional research and evaluation in this area is needed to better understand gender-specific similarities and differences. Further investigation, such as tracking campers' specific activity patterns from year to year, may suggest the specific camp components that impact life skill development and influence gender-specific gains.

An area of future study is changes in parent's perceptions and expectations of program providers. For example, over a period of eight years, cultural shifts in parenting practices may impact what it means to parents for their child to adapt well to change. Parents of this millennial generation have shifted towards being more involved in their children's activities and less encouraging of independence (Cline \& Jim, 1990). This trend towards parents taking responsibility for their actions of their children may be reflected in what parents perceive of, or expect from, the camp experience.

\section{Practical Applications}

Utilizing a standardized evaluation process and instrumentation over time and across sites can be a useful way to measure changes in program outcomes as well as overall program quality and consistency. Comparing results of standardized surveys may also reveal important differences among participant groups based on demographic or other criteria. Triangulating participant evaluation information with data collected from other stakeholder groups such as parents can yield relevant information about program impacts and areas of program improvement. A systematic approach to tracking youth activity involvement from year to year may help explain how different life skills are acquired and developed. This recommendation is consistent with Ferrari and McNeeley (2007), who suggested linking life skill development with camp design elements.

\section{References}

American Camp Association. (2005). Directions: Youth Development Outcomes of the Camp Experience. American Camp Association.

American Camp Association. (2007). Accreditation Process Guide. American Camp Association.

Arnold, M., Bourdeau, V.D., \& Nagele, J. (2005). Fun and friendship in the natural world: The impact of Oregon 4-H residential camping programs on girl and boy campers. Journal of Extension 46(6), Retrieved September 28, 2007 from http://www.joe.org/joe/2005december/rb1.shtml

Arnold, M., Bourdeau, V., Nagele, J. (2006, January/February) Do you know what your outcomes are? The impact of Oregon 4-H residential camp programs on positive youth development. Camping Magazine. American Camp Association. 
Ary, D., Jacobs, L.C., Razavieh, A., \& Sorensen, C. (2006). Introduction to research in education (7th ed.). Belmont, CA: Thomson Wadsworth.

Bialeschki, M.D., Henderson, K.A., \& James, P.A. (2007). Camp experiences and developmental outcomes for youth. Child and Adolescent Psychiatric Clinics of North America, $16,769-788$.

Brandt, J., \& Arnold, M.E. (2006). Looking back, the impact of the 4-H camp counselor experience on youth development: A survey of counselor alumni. Journal of Extension, 44(6).

Cline, F., \& Jim, F. (1990). Parenting with Love and Logic: Teaching Children Responsibility. Navpress.

Dillman, D. (2007). Mail and internet surveys: The tailored design method. New York: Wiley.

Ferrari, T.M., \& McNeely, N.N. (2007). Positive Youth Development: What's camp counseling got to do with it? Findings from a study of Ohio 4-H camp counselors. Journal of Extension, 45(2).

Fitzpatrick, J., Sanders, J., \& Worthen, B. (2004). Program Evaluation: alternative approaches and practical guidelines. Boston: Pearson.

Garst, B.A., \& Bruce, F.A. (2003). Identifying 4-H camping outcomes using a standardized evaluation process across multiple 4-H educational centers. Journal of Extension, 41(3). Retrieved September 28, 2007 from http://www.joe.org/joe/2003june/rb2.shtml.

Garst, B.A., \& Johnson, J. (2005). Adolescent leadership skill development through residential 4-H camp counseling. Journal of Extension, 43(5). Retrieved October 2, 2007 from http://www.joe.org/joe/2006december/rb2.shtml.

Garton, M.S., Miltenberger, M., \& Pruett, B. (2007). Does 4-H camp influence life skill and leadership development? Journal of Extension, 45(4).

Hendricks, P. (1996). Targeting Life Skills Model. Ames, Iowa: Iowa State University Extension, November.

Hines, S., \& Riley, L. (2005). Documenting impact is possible when working with camp program ,youth leaders. Journal of Extension, 43(3). Retrieved September 28, 2007 from: http://www.joe.org/joe/2005june/tt1.shtml.

Marshall, J.P., Higginbotham, B.J., Harris, V.W., \& Lee, T.R. (2007). Assessing program outcomes: Rationale and benefits of posttest-then-retrospective pretest designs. Journal of Youth Development, 2(1), Article 0701RS001. Retrieved March 25, 2008 from: http://www.nae4ha.org/directory/jyd/jyd article.aspx?id=0c614d6b-66f8-40ad-adc7c46f88467a6a

Rockwell, S.K., \& Kohn, H. (1989). Post-then-pre evaluation. Journal of Extension, 272). Retrieved September 28, 2007 from: http://www.joe.org/joe/1989summer/a5.html 
Thurber, C., Schuler, L., Scanlin, M., \& Henderson, K. (2007). Youth development outcomes of the camp experience: Evidence of multidimensional growth. Journal of Youth and Adolescence, 36, 241-254.

(C) Copyright of Journal of Youth Development Bridging Research and Practice. Content may not be copied or emailed to multiple sites or posted to a listserv without copyright holder's express written permission. However, users may print, download or email articles for individual use. 


\section{Appendix}

\section{Virginia 4-H Parent/Guardian Life Skills Evaluation}

Please take time and think about how your child may be behaving differently as a result of attending camp this year. [Using the 1 to 5 scoring system highlighted in the box below, circle the number that most closely corresponds to your child's behavior both BEFORE and AFTER attending 4-H camp.]

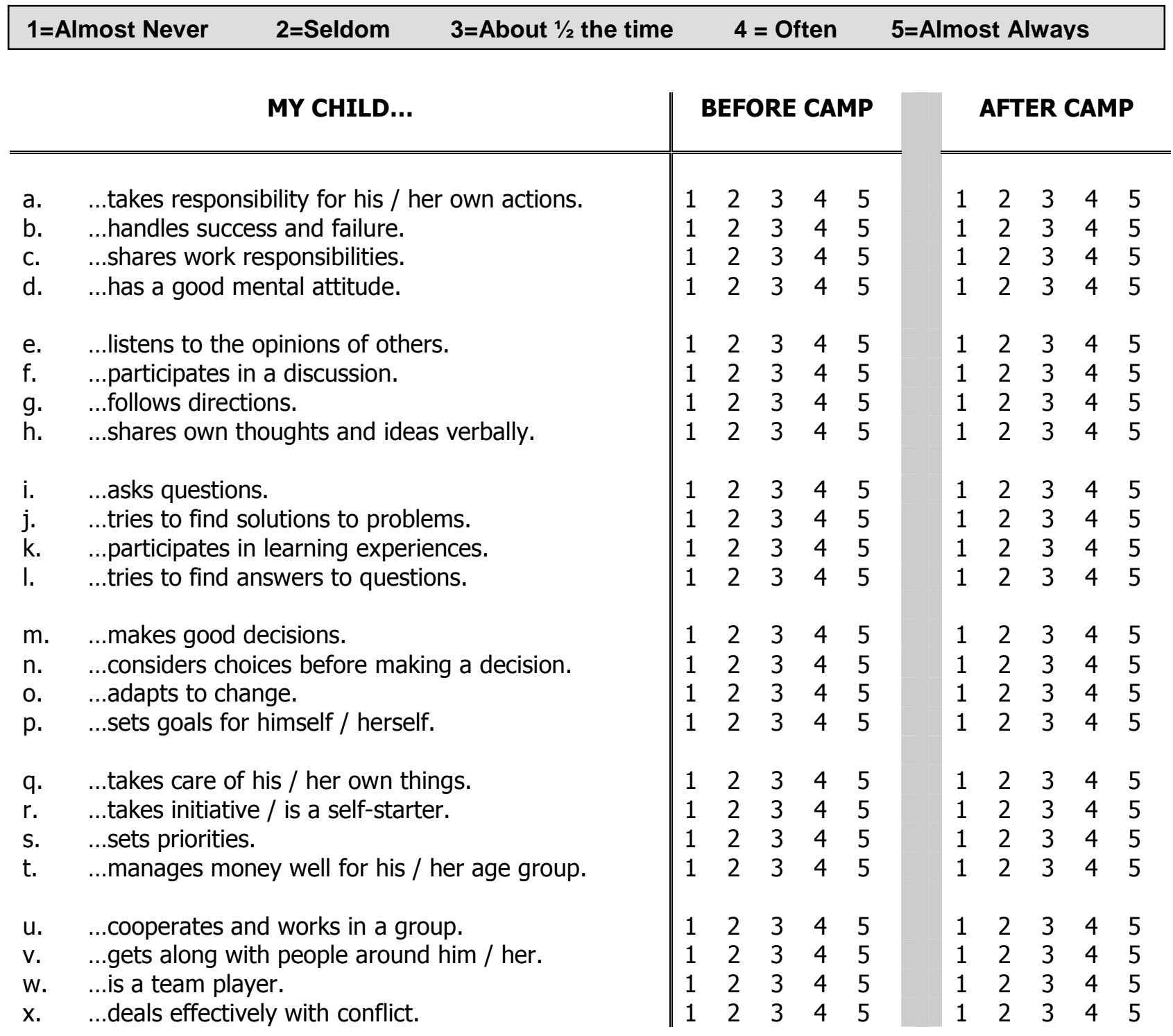

THANK YOU FOR YOUR TIME!

Developed by Dr. Barry A. Garst, Dr. Robert R. Meadows, Dr. F.A. "Lex" Bruce 